\title{
Lack of evidence for human infection with Xenotropic murine leukemia virus-related virus in the Brazilian Amazon basin
}

\author{
Samara Tatielle Monteiro Gomes ${ }^{[1]}$, Luciana Imbiriba ${ }^{[1]}$, Rommel Rodriguéz Burbano ${ }^{[2]}$, \\ Artur Luiz da Costa Silva ${ }^{[3]}$, Rosimar Neris Martins Feitosa ${ }^{[1]}$, \\ Izaura Maria Vieira Cayres-Vallinoto ${ }^{[1]}$, Marluísa de Oliveira Guimarães Ishak ${ }^{[1]}$, \\ Ricardo Ishak ${ }^{[1]}$ and Antonio Carlos Rosário Vallinoto ${ }^{[1]}$
}

[1]. Laboratório de Virologia, Universidade Federal do Pará, Instituto de Ciências Biológicas, Belém, PA. [2]. Laboratório de Citogenética Humana, Universidade Federal do Pará, Instituto de Ciências Biológicas, Belém, PA. [3]. Laboratório de Polimorfismo de DNA, Universidade Federal do Pará, Instituto de Ciências Biológicas, Belém, PA.

\begin{abstract}
Introduction: This study confirmed the absence of natural infection with Xenotropic murine leukemia virus-related virus (XMRV) or XMRV-related disease in human populations of the Brazilian Amazon basin. We demonstrated that 803 individuals of both sexes, who were residents of Belem in the Brazilian State of Pará, were not infected with XMRV. Methods: Individuals were divided into 4 subgroups: healthy individuals, individuals infected with human immunodeficiency virus, type 1 (HIV-1), individuals infected with human T-lymphotrophic virus, types 1 or 2 (HTLV-1/2), and individuals with prostate cancer. XMRV infection was investigated by nested PCR to detect the viral gag gene and by quantitative PCR to detect pol. Results: There was no amplification of either gag or pol segments from XRMV in any of the samples examined. Conclusions: This study supports the conclusions of the studies that eventually led to the retraction of the original study reporting the association between XMRV and human diseases.
\end{abstract}

Keywords: Xenotropic murine leukemia virus-related virus. Retrovirus. Amazon region. Brazil.

\section{INTRODUCTION}

Xenotropic murine leukemia virus-related virus (XMRV) was first identified by Urisman et al. ${ }^{1}$, who studied the correlation between XMRV infection and the R462Q mutation of the ribonuclease L (RNase L) antiviral protein in familiallinked cases of prostate cancer (PC). Schlaberg et al. ${ }^{2}$ detected XMRV proteins in malignant epithelial cells, although no correlation was observed between XMRV infection and the R462Q mutation. A similar lack of association was found in other studies performed in Mexico ${ }^{3}$ and the United States ${ }^{4}$.

The study of XMRV in blood samples from chronic fatigue syndrome (CFS) patients by Lombardi et al..$^{5}$ revealed that $67 \%$ of patients tested positive for the virus, compared to $3.7 \%$ in the control population. XMRV infection has also been investigated in patients with respiratory tract infections, and approximately $10 \%$ of immunodeficient patients were infected with XMRV,

\footnotetext{
Address to: Dr. Antonio Carlos Rosário Vallinoto. Laboratório de Virologia/ Instituto de Ciências Biológicas/UFPA. Rua Augusto Corrêa 01, Bairro Guamá, 66075-110 Belém, PA, Brasil.

e-mail: vallinoto@ufpa.br

Phone/Fax: 5591 3201-7587

Received 31 March 2014

Accepted 16 June 2014
}

compared to $3.2 \%$ of immunocompetent patients. In addition, salivary viral ribonucleic acid (RNA) concentrations in infected individuals, although relatively low, were suggestive of a potential transmission route ${ }^{6}$.

Xenotropic murine leukemia virus-related virus proteins were detected in $4.2 \%$ of Japanese people infected with human T-lymphotrophic virus, type 1 (HTLV-1), although this result may have been an artifact of the high degree of similarity between gp21 in HTLV-1 and p15E in XMRV. Positive serological findings from previous studies may have also been the result of cross reactions ${ }^{7}$; however, antibodies specific to the virus were apparently detected ${ }^{8,9}$. Other studies showed a prevalence of between 1-3\% in the general (i.e., healthy) population, which indicated a possible role of blood transfusions in the dissemination of the virus ${ }^{10,11}$.

New information about XMRV has raised controversy regarding the prevalence of the virus. Potential confounding factors include: a) the difficulty of reproducing results obtained for both the general population and patients with PC or CFS; b) the origin of the virus in relation to endogenous murine leukemia virus; $c$ ) the contamination of human blood and tissue samples with murine deoxyribonucleic acid (DNA); and d) the contamination of commercial polymerase chain reaction (PCR) reagents with potential sources of false-positive results ${ }^{12-14}$.

The results of subsequent studies involving PC and CFS patients failed to show detectable XMRV or found extremely 
low levels of proviral DNA in the samples, indicating that PCR detection of the virus is not always feasible or reliable ${ }^{13,15-17}$. In addition, the lack of an association between viral infection, new cases of PC, and the RNase L R462Q mutation further questioned the potential of XMRV as a human oncovirus ${ }^{14,18}$.

The present available data led to the retraction of the original data reporting an association between XMRV and human diseases ${ }^{19-21}$. A wide variety of infectious agents, many of which are capable of infecting humans, are endemic to the Brazilian Amazon. Thus, the present study aimed to determine the presence or absence of natural XMRV infection in human populations in the Amazon and its potential associations with diseases.

\section{METHODS}

\section{Sample collection}

DNA samples acquired in previous studies conducted at the Virus Laboratory of the ICB/UFPA were obtained from 803 individuals of both sexes who were residents of the City of Belém, State of Pará, Brazil. The subjects were divided into 4 groups as described in Table 1: healthy individuals $(n=290)$, individuals infected with human immunodeficiency virus, type $1(\mathrm{HIV}-1)(\mathrm{n}=292)$, individuals infected with HTLV-1/2 $(\mathrm{n}=107)$, and individuals with prostate cancer $(\mathrm{n}=114)$.

\section{DNA extraction}

DNA samples were extracted using the Pure Link Total DNA Kit (Life Technologies, USA), according to the manufacturer's instructions. Samples from the healthy individuals and HIV-1 and HTLV-1/2-infected individuals were obtained from leukocytes. DNA from patient PC samples was extracted from paraffin blocks and frozen tumor tissues.

\section{Molecular analysis}

Infection by XMRV was investigated using nested PCR to amplify a 413-bp fragment of the gag gene, as described previously ${ }^{10}$. In addition, the XMRV pol gene was detected by quantitative polymerase chain reaction (qPCR), using the StepOnePLUS ${ }^{\text {TM }}$ Real-Time PCR System (Life Technologies,
USA), as described by Schlaberg et $\mathrm{al}^{2}{ }^{2}$. Detection of the human glyceraldehyde 3-phosphate dehydrogenase (GAPDH) gene was used as an endogenous control for qPCR reactions. The AO-H4 and AM2-9 plasmids, encoding XMRV cDNA derived from viral RNA isolated from a prostate cancer specimen (VP62), were used as positive controls ${ }^{1}$. TaqMan FAM-labeled probes were designed to target conserved regions of both the XMRV gag and pol genes and in the GAPDH gene. Plasmid samples were kindly provided by Dr. Nicole Fisher of the Institute for Medical Microbiology, Virology and Hygiene, at the HamburgEppendorf University Medical Center in Hamburg, Germany.

\section{Ethical considerations}

The present study was submitted to and approved by the Ethics Committee of the Federal University of Pará (Number: 0024.0.324.324-11).

\section{RESULTS}

Analysis by qPCR indicated that the pol segments of XMRV were not amplified in any of the samples tested (Table 1 and Figure 1), although positive control templates (i.e., XMRV cDNA plasmids) and endogenous controls (i.e., GAPDH) were detected. Nested PCR also failed to amplify the targeted gag segment in patient samples, but it was amplified in the controls.

\section{DIscussion}

Xenotropic murine leukemia virus-related virus was initially regarded as a virus that was capable of infecting humans and being transmitted through similar routes to those used by other human retroviruses. It was additionally thought to occur in co-infections, for example with HIV-1 or HTLV, as proposed by Groom et al. ${ }^{16}$ and Qiu et al. ${ }^{9}$ Although a previous study described a high rate of HIV-1/HTLV-1/2 co-infection ${ }^{22}$, the present study did not find evidence for co-infection with XMRV among people infected with HIV-1 or HTLV-1/2, confirming previous results from HIV-1 carriers in Germany ${ }^{23}$.

TABLE 1 - Characteristics of the population groups investigated in the present study for the presence of XMRV infection.

\begin{tabular}{|c|c|c|c|c|c|c|c|}
\hline \multirow[b]{2}{*}{ Population } & \multirow[b]{2}{*}{ Number } & \multirow[b]{2}{*}{ Sample } & \multirow[b]{2}{*}{ Mean age $( \pm \mathrm{SD})$} & \multicolumn{2}{|c|}{ Gender } & \multirow{2}{*}{$\begin{array}{c}\text { Nested PCR } \\
\text { Gag }^{+}\end{array}$} & \multirow{2}{*}{$\begin{array}{l}\mathrm{qPCR} \\
\mathrm{pol}^{+}\end{array}$} \\
\hline & & & & male & female & & \\
\hline Healthy control & 290 & blood & $29.98 \pm 9.39$ & 102 & 188 & 0 & 0 \\
\hline HIV-1 & 292 & blood & $39.87 \pm 10.68$ & 176 & 116 & 0 & 0 \\
\hline HTLV-1/2 & 107 & blood & $46.82 \pm 15.76$ & 33 & 74 & 0 & 0 \\
\hline
\end{tabular}

XMRV: xenotropic murine leukemia virus-related virus; SD: standard deviation; PCR: polymerase chain reaction; qPCR: quantitative polymerase chain reaction; HIV-1: human immunodeficiency virus, type 1; HTLV-1/2: human T-lymphotrophic virus, types 1 and 2. 

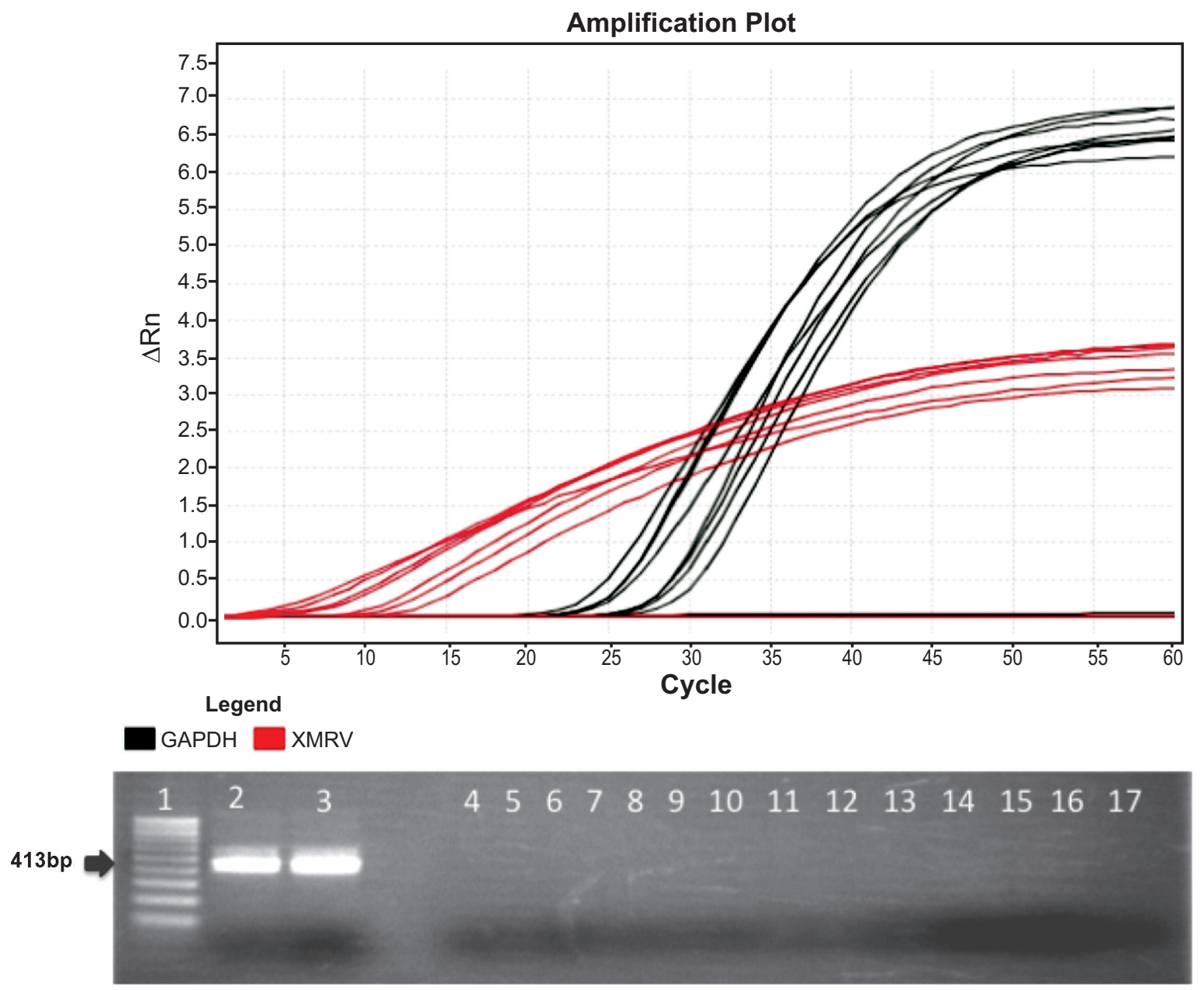

FIGURE 1 - A: Dose-dependent qPCR detection of the XMRV plasmid control (red) at concentrations of 333.6, 83.4, 20.8, 5.2, 1.3, 0.33 , and $0.08 \mathrm{ng} / \mathrm{uL}$ and $\mathrm{qPCR}$ detection of the $G A D P H$ gene (black). The $G A P D H$ gene was used as an endogenous control for qPCR reactions, and XMRV cDNA encoded in the AO-H4 and AM2-9 plasmids was used as a positive control for pol detection. All patient samples were XMRV-negative as assessed by real time PCR and nested PCR. B: Ethidium bromide staining of a $1.5 \%$ agarose visualized under UV light, showing nested PCR results for the amplification of a 413-bp fragment of the gag gene. Lanes: 1: 100-bp DNA ladder; 2-3, plasmid controls; 4-17, representative negative XMRV patient samples. $\Delta R \mathbf{n}$ (Delta $\mathrm{Rn}$ ) is the normalization of Rn (fluorescence of the reporter dye divided by the fluorescence of a passive reference dye) obtained by subtracting the baseline $(\Delta R n=R n-b a s e l i n e)$.

qPCR: quantitative polymerase chain reaction; XMRV: xenotropic murine leukemia virus-related virus; GAPDH: glyceraldehyde 3-phosphate dehydrogenase; cDNA: complementary DNA; UV: ultraviolet.

We also found no evidence of XMRV infection in prostate tumor samples, contradicting the results of previous studies that found an apparent association between this retrovirus and prostate cancer $^{1-4}$. Similar negative results were attributed to the failure of PCR procedures ${ }^{13,15-17}$. However, it is important to note that in the present study, nested and real time PCR were used, and both procedures were effective in detecting proviral DNA of HIV-1 and HTLV-1/2 in several different groups, even when viral copy numbers were extremely low ${ }^{24-27}$.

Several factors can interfere with the diagnosis of $\mathrm{XMRV}$ infections in humans. The most likely explanation for false positive results is contamination of commercial PCR reagents ${ }^{12-14}$. Additionally, Tuke et al. ${ }^{28}$ proposed that a specific Taq DNA polymerase may contain monoclonal mouse antibodies with varying quantities of murine DNA. This DNA is detectable in some batches and can thus generate false positive results. The results of the present study did not support this conclusion; the reagents used were provided by several different manufacturers, including the manufacturer used by Tuke et al. ${ }^{28}$, and no false positives were observed. It thus seems more likely that contamination of reagents, human blood or tissue samples with murine genomic DNA was restricted to only a few research laboratories, which would account for the divergence of results.

Paprotka et al. ${ }^{29}$ proposed that XRMV originated from a single recombination event between 1993 and 1996, involving 2 endogenous MLVs (i.e., PreXMRV-1 and PreXMRV-2) derived from a xenograft of the $22 \mathrm{R} v 1$ cell line in nude mice. The possibility that this recombination event occurred in multiple locations is highly unlikely, given the marked similarity of sequences isolated in different studies. XMRV was therefore 
considered a virus that originated from a single recombination event and did not have a natural human reservoir ${ }^{13,30}$. It thus seems likely that all the subsequent isolates of the virus were derived from this unique recombination event because of crosscontamination in various laboratories when handling $22 \mathrm{R} v 1$ and other susceptible cell lines. From 1999 onwards, 22Rv1 cell lines were distributed worldwide and were largely used in biological studies of prostate cancer ${ }^{29}$.

Clearly, there was no contamination in the present study. Furthermore, the absolute lack of XMRV in the various groups investigated herein challenges the results of previous studies that showed a high prevalence of XMRV in human populations and alleged an association with prostate cancer. This study supports the conclusions of studies that eventually led to the retraction of the original study reporting the association between XMRV and human diseases ${ }^{19-21}$.

\section{ACKNOWLEDGMENTS}

We thank all the individuals who participated in the present study.

\section{CONFLICT OF INTEREST}

The authors declare that there is no conflict of interest.

\section{FINANCIAL SUPPORT}

This study was partially supported by a grant from the Brazilian National Council for Scientific and Technological Development $(\mathrm{CNPq})$ and the Office of the Dean of Research and Graduate Studies (Pró-Reitoria de Pesquisa e Pós-Graduação - PROPESP/UFPA)/Research Support and Development Foundation (Fundação de Apoio e Desenvolvimento da Pesquisa - FADESP).

\section{REFERENCES}

1. Urisman A, Molinaro RJ, Fischer N, Plummer SJ, Casey G, Klein EA, et al. Identification of a novel gammaretrovirus in prostate tumors of patients homozygous for R462Q RNase L variant. PLoS Pathog 2006; 2:e.25.

2. Schlaberg R, Choe DJ, Brown KR, Thaker HM, Singh IR. XMRV is present in malignant prostatic epithelium and is associated with prostate cancer, especially high-grade tumors. Proc Natl Acad Sci USA 2009; 106:16351-16356.

3. Martinez-Fierro ML, Leach RJ, Gomez-Guerra LS, Garza-Guajardo R, Johnson-Pais T, Beuten J, et al. Identification of viral infections in the prostate and evaluation of their association with cancer. BMC Cancer 2010; 10:326.

4. Danielson BP, Ayala GE, Kimata JT. Detection of Xenotropic Murine Leukemia Virus-Related Virus in normal and tumor tissue of patients from the Southern United States with prostate cancer is dependent on specific polymerase chain reaction conditions. J Infect Dis 2010; 202: 28-35.

5. Lombardi VC, Ruscetti FW, Grupta J, Pfost MA, Hagen KS, Peterson DL, et al. Detection of an infectious retrovirus XMRV, in blood cells of patients with chronic fatigue syndrome. Science 2009; 326:585-589.
6. Fisher N, Schulz C, Stieler K, Hohn O, Lange C, Drosten C, et al. Xenotropic Murine Leukemia Virus-related Gammaretrovirus in Respiratory Tract. Emerg Infect Dis 2010; 16:1000-1002.

7. Qiu X, Swanson P, Tang N, Leckie GW, Devare S, Schochetman G, et al. Prevalence of XMRV in blood donors, HTLV and HIV cohorts. Retrovirology 2011; 8:A222.

8. Groom HCT, Yap MW, Galão RP, Neil SJD, Bishop KN. Susceptibility of Xenotropic Murine Leukemia Virus-Related Virus (XMRV) to retroviral restriction factors. Proc Natl Acad Sci USA 2010; 107:5166-5171.

9. Qiu X, Swanson P, Luk KC, Tu B, Villinger F, Grupta J, et al. Characterization of antibodies elicited by XMRV infection and development of immunoassays useful for epidemiologic studies. Retrovirology 2010; 7:68-83.

10. Barnes E, Flanagan P, Brown A, Robinson N, Brown H, McClure M, et al. Failure to detect Xenotropic Murine Leukemia Virus-Related virus in blood-borne viral infections. J Infect Dis 2010; 202:1482-1485.

11. Mikovits JA, Lombardi VC, Pfost MA, Hagen KS, Ruscetti FW. Detection of an infectious retrovirus, XMRV, in blood cells of patients with chronic fatigue syndrome. Virulence 2010; 1:386-390.

12. Smith RA. Contamination of clinical specimens with MLV-encoding nucleic acids: implications for XMRV and other candidate human retroviruses. Retrovirology 2010; 7:112-114.

13. Erlwein O, Robinson MJ, Dustan S, Weber J, Kaye S, McClure MO. DNA Extraction Columns Contaminated with Murine Sequences. PLoS One 2011; 6:e23484.

14. Garson JA, Kellam P, Towers GJ. Analysis of XMRV integration sites from human prostate cancer tissues suggests PCR contamination rather than genuine human infection. Retrovirology 2011; 8:13-15.

15. Hohn O, Krause H, Barbarotto P, Niederstadt L, Beimforde N, Denner J, et al. Lack of evidence for xenotropic murine leukemia virus-related virus (XMRV) in German prostate cancer patients. Retrovirology 2009; 6:92-102.

16. Groom HCT, Boucherit VC, Makinson K, Randal E, Baptista S, Hagan S, et al. Absence of Xenotropic Murine Leukemia Virus-Related Virus in UK patients with chronic fatigue syndrome. Retrovirology 2010; 7:10-19.

17. Ali MA, Dale JK, Kozak CA, Goldbach-Mansky R, Miller FW, Straus SE, et al. Xenotropic murine leukemia virus-related virus is not associated with chronic fatigue syndrome in patients from different areas of the US in the 1990s. Virol J 2011; 8:450-457.

18. Rezaei SD, Hearps AC, Mills J, Pedersen J, Tachedjian. No association between XMRV or related gammaretroviruses in Australian prostate cancer patients. Virol J 2013; 10:20.

19. Alberts B. Retraction. Science 2011; 334:1636.

20. Simmons G, Glynn SA, Komaroff AL, Mikovts JA, Tobler LH, Hackett Jr J, et al. Failure to confirm XMRV/MLVs in the blood of patients with chronic fatigue syndrome: a multi-laboratory study. Science 2011; 334:814-817.

21. Alter HJ, Mikovits JA, Switzer WM, Ruscetti FW, Lo SC, Klimas N, et al. A multicenter blinded analysis indicates no association between chronic fatigue syndrome/myalgic encephalomyelitis and either xenotropic murine leukemia virus-related vrus or polytropic murine leukemia virus. MBio 2012; 3:e0266-12.

22. Vallinoto ACR, Azevedo VN, Santos DEM, Caniceiro S, Mesquita FCL, Hall WW, et al. Serological evidence of HTLV-I and HTLV-II coinfections in HIV-1 positive patients in Belém, State of Pará, Brazil. Mem Inst Oswaldo Cruz 1998; 93:407-409.

23. Korn K, Reil H, Ensser A, Knöll A. No evidence of XMRV infection in immunocompromised patients and HIV-positive individuals from Germany. Infection 2012; 40:181-184.

24. Ishak R, Harrington Jr W, Azevedo VN, Eiraku N, Ishak MOG, Guerreiro JF, et al. Identification of human $\mathrm{T}$ cell lymphotropic virus type IIa infection in the Kayapo, an indigenous population of Brazil. AIDS Res Hum Retroviruses 1995; 11:813-821.

25. Vallinoto ACR, Ishak MOG, Azevedo VN, Vicente ACP, Otsuki K, Hall WW, et al. Molecular epidemiology of human T-lymphotropic virus type II infection in Amerindian and urban populations of the Amazon region of Brazil. Hum Biol 2002; 74:633-644. 
26. Ishak R, Vallinoto ACR, Azevedo VN, Vicente ACP, Hall WW, Ishak MOG. Molecular evidence for infection by HTLV-2 among individuals with negative serological screening tests for HTLV antibodies. Epidemiol Infect 2007; 135:604-609.

27. Machado LF, Ishak MO, Vallinoto AC, Lemos JA, Azevedo VN, Moreira MR, et al. Molecular epidemiology of HIV type 1 in northern Brazil: identification of subtypes $\mathrm{C}$ and $\mathrm{D}$ and the introduction of CRF02_AG in the Amazon region of Brazil. AIDS Res Hum Retroviruses 2009; 25:961-966.
28. Tuke PW, Tettmar KI, Tamuri A, Stoye JP, Tedder RS. PCR Master Mixes Harbour Murine DNA Sequences. Caveat Emptor! Plos One 2011; 6:e19953.

29. Paprotka T, Delviks-Frankenberry KA, Cingöz O, Martinez A, Kung H, Tepper CG, et al. Recombinant Origin of the Retrovirus XMRV. Science 2011; 333:97-101.

30. Cingöz O, Coffin JM. Endogenous murine leukemia viruses: Relationship to XRMV and related sequences detected in human DNA samples. Advances Virol 2011; ID:940210. 